\title{
Elogio da escola
}

\section{Praise of school}

https://doi.org/10.34112/2317-0972a2020v38n78p161-164

\section{Cristiane Fatima Silveira ${ }^{1}$}

LARROSA, Jorge (Org.). Elogio da escola. Belo Horizonte: Autêntica, 2017.

Pensar a Educação em uma reflexão sobre o que é a escola e seu caráter público é uma questão que, cada vez menos, permeia as pesquisas educacionais, visto que, em sua maioria, estas se direcionam à crítica da escola. O livro Elogio da escola (2017), organizado pelo filósofo espanhol Jorge Larrosa ${ }^{2}$, é uma obra que busca preencher essa lacuna, promovendo exercícios de pensamento sobre a escola, em sua composição, em contraponto àqueles que se preocupam apenas em instrumentalizá-la e fadar sua consequente dissolução.

Com esse intuito, Larrosa dá ao livro o título Elogio da escola, pensando na etimologia das palavras "elogio" e "escola". A primeira, de origem indo-europeia (latim elogium e grego elegeion), refere-se a uma inscrição feita sobre tumbas, para elogiar o defunto; e a segunda, de raiz grega (skholé), remete a "tempo livre", gerando a seguinte provocação: elogiar a escola talvez seja pensá-la, nesse momento em que se canta seu fim; profaná-la e refletir sobre tudo aquilo que faz com que a escola ainda seja um lugar de skholé, um tempo livre, um espaço público.

1. Mestranda do Programa de Pós-graduação em Educação da Universidade Federal de São João del-Rei (PPEDU/UFSJ).

2. Professor de Filosofia da Educação na Universidade de Barcelona. 
As reflexões são distribuídas pelas quatro partes da obra, sendo cada uma delas um conjunto de textos que dialogam entre si sobre a escola, tendo o livro Em defesa da escola: uma questão pública (2015) como potente provocador das discussões.

Na primeira parte do livro, os autores propõem um elogio à escola, pensando-a em sua forma e origem. Para isso, Masschelein e Simons apontam a existência de uma língua da escola, a qual necessita ser pensada a partir de uma perspectiva pedagógica, que dê voz às experiências e leve a nova geração a se expor (ao mundo). Esse aspecto é retomado por Kohan ao elogiar a vida de Masschelein, um educador que, em tempos de competitividade e individualidade na academia, põe-se a viajar com seus alunos, tendo a consciência de que, da mesma forma que a aprendizagem se dá pela exposição, a pedagogia também requer que o pedagogo embarque em uma viagem que o exponha.

Ainda junto com os pensamentos de Masschelein e Simons, Dussel propõe reflexões sobre os aspectos que permitem que a escola se mantenha de pé mesmo diante de sua apontada "precariedade" e dos "gigantes" que almejam substituí-la, como as tecnologias digitais, a autoaprendizagem, entre outros. Já Larrosa e Vanceslao resgatam as Missões Pedagógicas da II República Espanhola e sua proposta do "Museu Ambulante", para pensar as pessoas que experienciaram as Missões enquanto um povo capaz de skholé, de um tempo livre para vivenciar experiências, que, até então, lhe foram negadas.

A segunda parte do livro é composta pelo levantamento de "notas à margem" da obra Em defesa da escola: uma questão pública. Dussel, López, Kohan e Larrosa (junto com um grupo de alunos) apresentam argumentos, e os autores do livro escrevem um complemento para cada texto, elucidando as questões. Ricas reflexões são realizadas ao se pensarem experiências vivenciadas na escola envolvendo diferentes temáticas, tais como: popularização e instrumentalização da escola, formação de professores, dentre outras.

$\mathrm{Na}$ terceira parte, a escola é pensada a partir de diferentes produções: um filme, uma exposição e um exercício de pensamento coletivo. O filme Teoria da escola, produzido por Maximiliano López, foi trazido por ele com o intuito de provocar reflexões acerca da escola pública e de nossa maneira de estar nela. Já a exposição Educação como matéria-prima, realizada no Museu de Arte Moderna de São Paulo, em 2016, é resgatada por Leyton enquanto espaço que possibilitou ao público

3. Obra lançada no ano de 20I5, de autoria de Masschelein e Simons. 
experiências significativas de educação e tempo livre, partindo de uma potente reflexão acerca do museu enquanto espaço que, assim como a escola, permite a ressignificação e a criação de conhecimentos.

Encontramos, ainda, na escrita coletiva de Larrosa, Malvacini, Rechia, Augsburger, Favere e Cubas, a proposta de se pensar um desenho da escola, o qual seria possível ser feito a partir de uma escuta e de um olhar atentos para tudo aquilo que faz com que uma escola seja uma escola. Ela foi pensada em sua forma/origem em derivas urbanas, as quais foram materializadas, posteriormente, em uma exposição.

Já na quarta e última parte do livro, as reflexões são movidas por filmes, que mostram a escola com a necessidade de colocá-la em proeminência. Oubiña apresenta um olhar radical sobre a infância, presente no filme Zero de conduta, dirigido por Jean Vigo, enquanto Rechia e Cubas propõem pensar a escola na escola, a partir dos filmes catalães Elogi de l'escola e Escolta, em seus aspectos relacionados ao escrever, sentir e pensar sobre a escola. Por fim, Lima provoca uma reflexão acerca da infância e suas topologias a partir do documentário Ser e ter, de Nícolas Philibert, pensando os espaços habitados pelas crianças como topologias das relações, onde se expressam e se entendem no tempo e nos encontros entre gerações.

As produções cinematográficas se mostraram potentes para se pensar a infância e a escola. Os filmes, ao longo do livro, constituem parte deste movimento de "elogiar" a escola, mas não a idealizando. Vale ressaltar que acompanha o livro um DVD, com os filmes: Teoria da Escola, Elogi de l'escola e Escolta, além de registros das exposições Educação como matéria-prima e Desenhar a escola: um exercício coletivo de pensamento (oriundas das derivas urbanas de Larrosa e seus companheiros).

Em suma, Elogio da escola traz consigo a ideia de uma homenagem a essa forma que proporciona tempo livre e espaço público para vivenciar ricas experiências de encontros com o outro, com a cultura e, mais que isso, consigo mesmo. Em todos os textos, a escola é elogiada em sua forma, algo que está longe da profusão de críticas destinadas a ela. A única crítica presente na obra é direcionada àqueles que veem a escola enquanto instituição inútil e antiquada. Esse olhar antiescolar, por sua vez, terá no livro um convite para ver a escola com uma boa dose de reflexão.

A proposta do livro se mostra relevante para se pensar a escola enquanto espaço que é constantemente alvo de julgamentos, os quais, muitas vezes, são proferidos por sujeitos que sequer estão envolvidos no processo educativo. A escola precisa ser elogiada, resgatada em sua forma/origem, pois é espaço de humanização, sendo 
por meio dela que se torna possível a renovação do mundo, levando cada geração que vivencia este "tempo livre" a (re)inventá-lo.

Larrosa traz, em suas falas, não somente no referido livro, a ideia de um elogio à escola, afirmando que ela é um potente espaço para a promoção de reflexões sobre o mundo, sendo um refúgio para as crianças, a fim de que tenham tempo e espaço (livre/público) para contemplar as "maravilhas" do mundo, que seriam as coisas que nos tocam subjetivamente e que admiramos. Indo além, Larrosa diz que a própria escola é uma "maravilha" e que, portanto, deve ser contemplada, observada atentamente, não como um objeto, mas como forma que merece atenção, pois, apesar de se mostrar frágil, é consistente e se mantém de pé mesmo diante de sua proclamada "precariedade".

A organização de Larrosa se faz pertinente a diferentes sujeitos. Professores? Pesquisadores em Educação? Filósofos da Educação? Não somente! É um potente instrumento para todos aqueles que se movem pela iniciativa de promover um elogio à escola, em oposição à abundância de críticas sofridas por ela, resgatando-a enquanto skholé, um tempo livre e espaço público, e mais: enquanto tempo e espaço de resistência, consistência e perpetuação das "maravilhas" do mundo e da vida.

\section{SOBRE A AUTORA:}

Cristiane Fatima Silveira é graduada em Pedagogia pela Universidade Federal de São João del-Rey e Mestranda do Programa de Pós-Graduação em Educação da mesma universidade. Tem experiência na área de Educação, com pesquisa nos seguintes temas: Educação, Cinema, Desenho Infantil, Arte-Educação e Filosofia com crianças. É membro do Grupo de Pesquisa em Educação, Filosofia e Imagem (GEFI).

E-mail: cristianesilveirapedagogia@gmail.com.

Recebido em 19 de dezembro de 2018 e aprovado em os de março de 2020. 